Canadian Journal of Higher Education Revue canadienne d'enseignement supérieur Volume 42, No. 2, 2012, pages 34-48

\title{
Safety in the Classroom: Safeguarding Liberal Arts Education from the Neo-Liberal Threat
}

Arielle Dylan

St. Thomas University

\begin{abstract}
This article examines the elusive concept of safety in liberal arts classrooms which are often contoured by a plurality of social, cultural, political, psychological, historical, and discursive forces and performances. Using select principles from adult education and social work with groups as an organizing metaphor, the article discusses the classroom as a large group, the changing student body, and, especially, the impact of diversity and inclusivity in liberal arts settings. Because the aim of liberal arts education is usually to promote independent and critical thinking, open-mindedness, and greater communication and decision-making skills, its goals foster, to a great degree, citizen engagement that empowers persons to participate in collective actions toward greater equality and justice in communities both locally and globally. Classroom safety is essential to these aims because it increases opportunity for free, critical, and independent thought necessary for progressive, egalitarian, and justice pursuits. The article explores safety, including dialogic practices and reflection on relations of power within the classroom, for its significant role in fulfilling liberal arts aspirations.
\end{abstract}

\section{RÉSUMÉ}

Cet article examine le concept problématique de la sûreté dans les classes où se donnent des cours de formation générale, souvent entourées d'une pluralité de performances et de forces sociales, culturelles, politiques, psychologiques, historiques et discursives. En utilisant des principes de choix de l'éducation aux adultes et du travail social en groupes comme métaphone organisationnelle, définissant ainsi la salle de classe comme un grand groupe, nous discutons de l'évolution de la population étudiante et, surtout, de l'effet de la diversité et 
de l'inclusivité dans des installations où l'on dispense la formation générale. Puisque l'objectif principal d'une formation générale consiste habituellement à promouvoir la pensée indépendante et critique, l'ouverture d'esprit et de meilleures aptitudes en communication et en prise de décision, ces objectifs intermédiaires encouragent, jusqu'à une certaine mesure, la gestion du citoyen qui autorise les gens à participer à des actions collectives qui mènent à une plus grande égalité et justice au sein de communautés, tant à l'échelle locale que planétaire. La sûreté des salles de classe est essentielle pour réaliser ces objectifs, car elle augmente la possibilité de générer une pensée libre, critique et indépendante, nécessaire aux activités progressives, égalitaires et justes. Cet article explore la sûreté, incluant les pratiques dialogiques et les réflexions sur les relations de pouvoir dans la salle de classe, pour son important rôle qui consiste à réaliser les aspirations d'une formation générale.

Canada has the distinction of being among those countries having the highest rates of university enrolment in the world (Statistics Canada, 2011). Yet participation in postsecondary education alone does not reveal whether the pursuit of higher education in the current socio-political climate contributes to the public good or advances the corporate agenda. In this era of neo-liberalism and technical rationalism where corporatization, internationalization, and the evisceration of government funding have trumped democratic endeavours and social justice values, the university is at risk of becoming little more than a feeder for the workforce (Adamuti-Trache, Hawkey, Schuetze, \& Glickman, 2006; Giroux, 2011). What becomes of liberal arts education in the face of the neo-liberal juggernaut where global economic practices corporatize public spaces, including academic institutions, and threaten to reduce education to a commodity assessed by performance indicators (McKernan, 2005)? This job-readiness ethos so central to the corporate ideology assaulting universities is anathema to the very principles of liberal arts whose deep historical roots are in the holistic development of the person and, through a number of permutations in the past century, have come to include a moral imperative to participate responsibly in community life, and the important goal of becoming an agent of social justice and corresponding social change (Axelrod, Anisef, \& Lin, 2001; Zlotkowski, 2001). With the growing dominance of global competitiveness and its attendant Darwinian values promoting what McKibben (2007) aptly termed hyperindividualism, not only are liberal arts at risk but the very continuance of the university as a "utopian space" where "vital issues are investigated, discussed, reflected on" is under threat (Said, 1994, p. xxvi).

University curriculum in the 21st century is inherently difficult: most material lacks certainty and there are no objective, value-free facts (Fleck-Henderson, 2002). The Derridean dilemma of inhabiting a world without safe ground on which to base decisions, without clean, unambiguous positions or conclusions, can heighten student anxiety. Few are proficient in Keatsian "negative capability" in which being in a state of uncertainties does not induce discomfort (Perkins, 1967). Similarly, new learning approaches can be intimidating for students who have grown accustomed to the "bank deposit," student-asreceptacle method that Freire (1970) critiques. Although hooks (1994) saw "education as the practice of freedom" (p. 207), such freedom can elicit fear in learners who have 
been well indoctrinated into traditional teaching methods (Mayo, 1999). Adult education theory contributes the important concept that self is central to learning, but many students may not be familiar or comfortable with this approach and struggle with the expectations of this style. When curricular and classroom issues are considered together with student learning and discussion styles, and possible socio-structural obstacles, it is understandable that the task of classroom participation, which hinges so strongly on safety, could prove challenging. The increasing corporatization of university spaces and overt orientation toward markets tends to elicit from students, especially those who perceive university education as job-readiness training, a desire to learn precisely what they need to know to be prepared for the market. This phenomenon coupled with the growing number of students lacking preparedness for higher education makes difficult the pursuit of liberal arts objectives. This paper examines the role classroom safety can play to assist liberal arts goals in this time of neo-liberal threat. Classroom safety, in this paper, is recognized both as a nested issue residing in the larger question of the extent to which liberal arts and academic spaces more broadly are imperilled and as a strategic approach to countering the neo-liberal assault on university education.

\section{CLASSROOM SAFETY}

Safety is a factor in every classroom, in every discipline, whether a large lecture format or a small seminar group. In university classes where learning is increasingly didactictheoretical and experiential-affective, where adult learning principles invite sharing of academic and personal knowledge, the risks can be high and classroom safety becomes a central consideration in the learning environment (Garcia \& Melendez, 1997; Plionis \& Lewis, 1995). Although literature addressing the topic of classroom safety has often focused on courses addressing multiculturalism and oppression, safety is a variable in all university classrooms as the overdue shift toward non-canonical works and a critique of long-standing, positivistic narratives has infused course content more broadly with diversity and anti-oppression themes. Deconstructive strategies, for those who are uninitiated or unprepared, can sometimes create in-class rancour where some members may be accused of tribalism or particularism (Gutmann, 1994). Moreover, deconstruction and forms of postmodernism that lack a strong critical perspective can leave students feeling hamstrung about how to move forward constructively (Fook, 2002), weakening the possibility of developing engaged proactive citizens and encouraging emergent theories for a transformed socially just society and polity. Compositionally, classes are inherently diverse, and this diversity surfaces unique classroom dynamics, for social power differentially contours individuals (Mayo, 1999). The most seemingly homogeneous group of students (e.g., a class of white, middle-class women) will be diverse, each learner bringing her own politicized biography, and this fact requires attending to both the compositional and the content layers of diversity within a classroom. The effort to create classroom safety will be aided by being mindful of these realities, understanding the dual position occupied by students and instructors where both are educators and learners (Giroux, 1999), making use of select adult learning approaches and group work principles, and applying important aspects of critical thinking and critical theory. Given the myriad variables that can affect classroom safety, striving toward this goal is, of course, an aspirational practice. 
Before proceeding, several questions need to be answered: What is safety? For whom is safety? Who determines safety? Who monitors and ensures safety? For which discourses does safety apply? An obvious answer, and ideal situation, is safety is for everyone, delineated by and regulated by everyone, and safety should be applied uniformly. A class that is highly sensitive to issues of race may be less sensitive to issues of gender, sexual orientation, and ethnicity. A class that would welcome a Tibetan Buddhist nun may be resistant to a Christian nun because of a tendency to exoticize the one and monolithically and negatively reify the other, when instead the need is to nurture pluralism, critical exploration, and the discussion of different views. The question becomes, How are university classrooms kept truly safe for everyone without lapsing into a professional brand of doctrinaire parochialism where discussions lack nuance and safety amounts to little more than facile jargon and political correctness (Humphries, 1997)? As Giroux and Giroux (2003) would have framed it, How is the line between "critical teaching and demagoguery" (p. 4) maintained? There is a significant divide that separates critical theorizing and exploration from propagandizing. Although safety is the responsibility of both teachers and students, and classroom safety can be reinforced by particular methodologies coupled with critical thinking, absolute safety itself is an unattainable construct. That is, safety can be promoted but not created; safety can be desired but never perfectly achieved, for classrooms cannot overcome injustices of unequal social power (Briskin, 1998a). Risk-taking and challenges, often associated with profound learning moments, do not need to occur in lieu of safety (Hyde \& Ruth, 2002). A student should be able to take risks, experiencing discomfort, knowing that the learning environment is safe; in such an environment, the student will be listened to, heard, not interrupted, not judged, countered respectfully, and not subject to ad hominem attacks (Garcia \& Melendez, 1997). Even the idea of students and instructors sharing the responsibility of classroom safety presents its own set of challenges, as both can feel unsafe for a variety of reasons: being evaluated, fear of criticism and judgment, social or political location, and so on.

\section{CLASSROOM ISSUES}

Although it is true that courses containing substantial content on diversity and equity issues can be more politically charged, potentially leading to "deep-seated dissonance and distress" (Van Soest, 1996a, p. 200), strong emotions and strained interactions can arise in any course. Indeed anecdotal reports from colleagues teaching in a number of university institutions in Canada and other Western nations indicate students have felt isolated and disrespected, unsafe and vulnerable in a variety of university courses. Understandably, disturbances could erupt more easily in courses where equity, diversity, and anti-oppressive considerations are discussed more overtly and deliberately, but all university courses since the toppling of grand narratives and the rethinking of disciplinary canons involve critical content, increasing the possibility of intrapersonal, interpersonal, and intragroup conflicts. In learning new material and coming to question received assumptions, students can feel personally overwhelmed by the magnitude and pervasiveness of systemic forms of oppression, their previously unexamined role in inadvertently supporting oppressive structures, and feelings of guilt, shame, anger, fear, frustration, and resentment can ensue (Garcia \& Melendez, 1997; Garcia \& Van Soest, 1999). 
In discussions critiquing the status quo, examining the role of social construction in perceived social reality, and the power of discursive formations to shape thoughts, ideals, and public spaces, students' understanding might initially be limited making them question their ability to contribute in a meaningful manner (Bronstein \& Gibson, 1998; Plionis \& Lewis, 1995). Some students fear risking participation will lead to disparagement, others take risks and feel betrayed upon discovering the class lacks the safety presumed, while others participate in a self-censored manner, rather than dialoguing openly, stating normative views they trust will be well received (Briskin, 1998b; Hyde \& Ruth, 2002; Plionis \& Lewis, 1995). Although the self-learning potential in university classrooms is significant, critical exploration can threaten core values, potentially creating an unsettling distance between long-held beliefs and newly discovered personal dimensions (Garcia \& Van Soest, 1999). This experience, however, is what constitutes a good education, instilling "a critical sense, a kind of nasty, demanding, questioning attitude to everything that's put before you" (Said, 2001, p. 225). But this transformative process of moving from unchecked core beliefs to self-examination to new understanding requires an ability to manage affect as well as a framework in which student feelings can be supported and legitimized (Garcia \& Van Soest, 1999). This process requires a "perspective transformation," a shift in worldviews as articulated by Mezirow (1991), with the aim of providing alternative, useful perspectives and practices that counter the "long legacy among educators and academics to engage in forms of criticism that appear unconnected to the discourse of possibility and hope" (Giroux, 2008, p. 179).

\section{CLASSROOM NORMS}

One of the most powerful means for promoting classroom safety, borrowed from the methodology belonging to social work with groups, is the establishment of agreements or norms near the beginning of the term, if not at the first meeting. This strategy helps build a culture of safety and "provides support and security" for students which "contributes to the development of cohesion" (Northen \& Kurland, 2001, p. 306). Instructors can facilitate the generation of these agreements as a collective process by asking what is required in order to dialogue freely in the classroom. Mutually producing a set of conversational parameters is an uncomplicated brainstorming exercise with which many will be familiar and can easily participate. By communally generating a set of classroom norms, students experience the guidelines as their own. If an instructor finds it necessary to intervene during a classroom conflict, and perhaps even redirect a conversation, this action is less likely to be perceived as authoritarian, especially if the class-generated norms are referenced. Agreements of this kind can be useful for all post-secondary courses. Such norms anticipate the possibility that sensitive or difficult issues may arise during class discussions, and they support a safe learning environment through providing concrete strategies for resolution that are available to both instructors and students. Students are freer to share ideas and take risks in a climate that does not countenance abusive comments or behaviours, and the norms underscore the requirement that student dialogue be respectful and cooperative (Raske, 1999). Deliberately striving to create a safe learning environment, which invites open communication and critical pedagogy, supports the "fundamentally dialogical character" of the human condition, helping to promote self-understanding, identity development, and the capacity to act as a critical agent in the world (Taylor, 1994, p. 32). 
The very structure of a set of classroom norms, increasing as it does individual and group security through transparency, can expand student dialogue, engendering student willingness to share thoughts about often difficult subject matter, such as race, gender, sexual orientation, class issues, disabilities, and so on. Although norms can provide the format for difficult and sometimes contentious class discussion, they are only effective if the instructor refers to them when necessary. In this respect, instructors must operate as active group workers. Students benefit from teachers intervening to ensure a safe environment when arguments escalate, become chaotic, or deteriorate into personal attacks (Van Soest, Cannon, \& Grant, 2000). Such interventions demonstrate that the desire to achieve safety is genuine, and the guidelines represent important class values that are to be upheld by everyone. To intervene in a timely fashion, the instructor must constantly attend to classroom dynamics, including affective components; otherwise a teaching moment can be irretrievably lost (Garcia \& Van Soest, 1999). This focus on classroom dynamics, its various subtleties and constant shifts, can benefit from the group work notion of the characteristic tension between "following" and "leading," where the instructor must skilfully move between these two roles, while simultaneously being aware of personal values and inclinations as an instructor which will invariably influence classroom dynamics (Cohen \& Mullender, 2003). The ability of instructors to examine critically their own predispositions, which is both a reflective and reflexive art, and to suggest rather than insist (Zalstrow, 2008) does much to protect against the propagandizing that Giroux and Giroux (2003) shrewdly cautioned against. When a classroom situation requires intervention, a number of possible strategies can be used, including seeking clarification, asking for supporting evidence, calling a brief time out, and reminding learners of the classroom norms. Deft and caring handling of an in-class conflict and breach of classroom norms can contribute to the learning process, offering an opportunity for transformative growth not only through creating a safer forum for critical, respectful classroom dialogue but also through well-modelled skills.

\section{TEACHER BEHAVIOUR AND APPROACH}

Modelling good communication has the potential to dramatically increase classroom safety. When a student's comments reflect anti-Semitism, ableism, homophobia, or other discriminatory and oppressive forms, and an instructor corrects respectfully without censure or derision, students learn how they can effectively intervene in similar circumstances (Northen \& Kurland, 2001; Raske, 1999). Theoretically, instructors are modelling skills and inclusivity values throughout each class and during every student-teacher interaction. The instructor who models effective and responsible use of power uses an empowerment model in the context of the educator-student learning relationship, and strives for congruency between content and methodology, promoting classroom safety while simultaneously reinforcing egalitarianism and anti-oppression values (Campbell, 2002; Raske, 1999). An instructor can achieve a great deal through action. For example, instead of promulgating his or her own views, the instructor who encourages students to explore and express their thoughts and feelings strengthens the experience of a nonhierarchical, shared learning environment. Moreover, if instructors interrupt dialogue only to safeguard a set of clearly established conversational parameters, never to advance personal, institutional, or "correct" views, students experience an enlargement of the dis- 
cursive realm where intellection can range freely without theoretical, ideological, or doctrinaire constraint. Although not necessarily easy to do, this practice is one toward which educators can endeavour.

Unfortunately, teachers can model as much by what they do not do as by what they do. Teachers who never discuss discrimination, oppression, geopolitical realities, and global inequities in this corporatized world can lead students to understand that such issues are unimportant, not within the purview of class discussion, or too inflammatory to be investigated, or they may leave students thinking there is only one view, that promulgated by the dominant culture. Similarly, teachers who do not articulate oppression concepts together, neglect intersectionality, and speak only of siloed oppressions, inadvertently reinscribe a hierarchy of oppression model (Hulko, 2009; Mehrotra, 2010). Engaging intersectionality and highlighting the reality of multiply constituted identities-not only individual but cultural, regional, and national-helps students gain a better understanding of complexities and prevents the unintended foregrounding of issues. Although some instructors would like to introduce issues of oppression, inequities, intersectionality, and a critique of the existing order in their classroom, they hesitate to do so for fear of potentially tensionfraught discussions that could ensue. But a commitment to critical pedagogy must be pursued in the university, and especially liberal arts programs, to continue nurturing socially conscious, critical citizens who see themselves as agents of change and are prepared for meaningful citizen engagement (Mulcahy, 2009; Vainio-Mattila, 2009). The purpose of a liberal arts education is to prepare persons to "identify and challenge those injustices that contradict and undercut the most fundamental principles of freedom, equality, and respect for all people who constitute the global public sphere" and to cultivate the ability to conceive and co-create alternative social and political futures (Giroux \& Giroux, 2003, p. 6). If instructors are uncomfortable with this task, if they do not feel well equipped to guide skilful exploration of justice considerations, then teacher training is necessary, for liberal arts classes are incomplete without this level of critical pedagogy.

\section{TEACHER AS FACILITATOR}

The university instructor teaching baccalaureate or graduate classes operates largely as a "facilitator of group process, helping students to attend to the business of building relationships, defining needs and goals, and negotiating how they will work together" (Coates \& McKay, 1995, p. 34). As Shulman (1987) asserted, there is a "hidden group in every classroom" (p. 3). The instructor can use small group principles to promote classroom safety, facilitate task completion, and aid in the maintenance of learners' collegial classroom relations. A classic group work technique that can be used is a circular seating arrangement, reflecting egalitarianism and adding to class safety through the literal and symbolic removal of hierarchical seating arrangements. The circle also serves as an apt metaphor for the cyclical movement of class discussions where topics or particular themes are revisited and expanded upon throughout the course. With safety guidelines in place, the facilitator can create an environment in which students are more willing to take risks, where they possess the confidence to trust their thoughts and instincts, where they can engage in theoretical and experiential learning, where they can be both active and reflective. Beginning with brief class check-ins and providing opportunities for students to work collaboratively through group activities can engender safety (Coates \& McKay, 1995; Freeman \& Valen- 
tine, 1998). Group activities should begin with low risk and progress to higher risk later in the term (Coates \& McKay, 1995) once the "performing" stage has been reached, after the initial awkwardness that characterizes most newly formed groups (Garland, Jones, \& Kolodny, 1973). Also, small group discussion and planned activities within the larger group can be used to facilitate working through more challenging material (Garcia \& Van Soest, 1999) and to encourage involvement of quieter, less participative students.

The ideal classroom environment is one in which everyone feels comfortable participating. For a variety of reasons, however, this environment is not always possible despite an instructor's strategies to promote a safe and inclusive atmosphere. Silence is often, though not always, associated with power dynamics. Some students are silenced because they feel alienated or marginalized based on race, ethnicity, gender, ability, and so on, and some students are silenced because they have experienced an abuse of power (e.g., harassment or bullying) with a class member outside the classroom setting. In the latter case there is little an instructor can do beyond engaging the formulated safety structures, ensuring such abuses of power do not occur in the classroom, and, if the tension or discomfort persists, checking in with the aggrieved individual to inquire about her or his well-being and employ appropriate channels for addressing the issue. Histories students have with each other can exercise a profound influence on classroom dynamics.

More can be done with respect to larger abuses of power, such as sexism, for example. There can often be power issues that unfold around gender issues, especially in classes with a roughly equal number of both sexes, but also in classes comprising mostly women: "Numerical domination of women does not necessarily translate into power" (Briskin, 1998a, p. 24). Most men and women have been socialized since childhood in educational settings in which boys enjoyed greater privilege than girls and were entitled to claim a significant portion of discussion and teacher time. It can be reasonably argued that "collaboration and group work are not in themselves solutions; if the organization of group work does not take account of power dynamics, group work itself can reinscribe power relations rather than create openings for more inclusive learning" (Briskin, 1998a, p. 24). Simply prompting women to speak is not sufficient, because this approach situates the problem within the individual, the woman, when in fact the issue is possibly larger, systemic, and structural. Moreover, the view that "both sexes equally need re-educating" is a "kind of 'humanism' [that] can hide power dynamics which heavily favour boys" (Briskin, 1998a, p. 26).

An instructor can intervene in troubling power dynamics by identifying the "problematic of power that exists in ... groups" and initiating a discussion about group dynamics that provides a significant learning opportunity, particularly if marginalized and alienated individuals contribute (Briskin, 1998a, p. 24). Instructors can also engage women and other power-compromised groups by being especially attentive to, and frequently scanning the room for, non-verbal cues, with the ultimate goal being an inclusion of all voices and all ways of knowing (Merdinger, 1991). This inclusion should embrace healthy silence (i.e., silence not stemming from inarticulate marginalization) as a viable participatory option. The primacy placed on garrulousness over introspection, on speaking rather than silence, is a Eurocentric proclivity that must be re-examined if classroom safety is designed and promoted for students of all ethnocultural backgrounds. Sometimes, through misguided inclusion efforts, instructors have on occasion unwittingly diminished safety by viewing certain students "as 'spokesperson' on behalf of their racial/ethnic group" (Nagda 
et al., 1999, p. 439); while the intention might be creditable, the net effect is a reinforcing of essentialism at best and stereotypes at worst. What is being recommended here is an educational approach and environment that does not encourage one voice at the expense of others but is inclusive of diverse voices, underscoring the multiplicity of subjectivities that exist inseparably from processes of systemic and structural oppression.

In this approach, abstract universalism is eschewed "because it's usually the universalism of whoever happens to be most powerful" (Said, 2001, p. 390). We must name and address issues rather than obfuscating them in codes and ideologies, rendering them impassable through what Popper (1994) described as "the cult of incomprehensibility."

\section{CRITICAL THINKING}

The processes of interrogation, recognition, and articulation are all enhanced by critical thinking skills. For university educators and learners, an appreciation for critical analysis and sound argumentation is essential to the objective of graduating persons capable of civic engagement and imagining an alternative future. The best place to overcome internal and external ignorance and prejudices is in the classroom where it is possible for learning to strengthen reason and advance intellectual interest, while militating against impulsivity and insularity. Critical thinking skills have long been recognized as a key component of social work education, because they form the cornerstone of sound judgment and good clinical practice (Alter \& Egan, 1997; Mumm \& Kersting, 1997). Sadly, with the commodification of higher education, critical thinking and the urgency to grapple with the complexities of the modern, globalized world have been attenuated.

But liberal arts educators must teach students critical thinking skills not only to foster the development of persons with democratic values and a propensity for social justice, but also to enhance learning and safety in classrooms. Much of the loaded quality of classroom discussion could be mitigated if all students clearly understood critical thinking skills and were able to distinguish reason from reflex, and rational from irrational views both within themselves and their classmates. "A rational ideology is sensitive to a body of basic data that is continually and cumulatively influenced by proximate beliefs and normative and empirical experiences" (Van Soest, 1996b, p. 57). A defining characteristic of rational ideology is its accountability to external evidence, unlike irrational ideology that is not accountable to external evidence and can sometimes be nothing more than dogma (e.g., the concept of the undeserving poor). If critical thinking were included as a norm in class discussions, making logical fallacies (e.g., ad hominem, ad verecundium, diversion, stereotyping, groupthink, bandwagon, either-or, and straw person arguments) readily identifiable and unacceptable, the conversational terrain could change considerably. Participants would be required to support statements, political positions, and personal opinions with solid argumentation: This requirement would diminish the reactionary and occasionally incendiary comments made, and it would provide a group-sanctioned mechanism for their defusing. By considering whether or not a position is logical, how a position is situated with respect to other positions or theories, and whether or not a position fits with the values of open, respectful discourse in a liberal arts setting, students can become aware of errors in reasoning-both their own and others.

This is not to suggest that students without critical thinking training are incapable of logical thought, only that knowledge of fundamental critical thinking skills promotes re- 
flective thought that better facilitates decision making and informed behaviour and actions (Biesta \& Stams, 2001). With so many opinions disconnected from knowledge in an information-barraged society, the challenge of meaning making and attending to meaningfulness is great (Kingwell, 2001). Critical thinking skills could help students make sense of a postmodern reality, serving as a compass of reason to facilitate interpretation in a world lacking uncontested grand narratives. The whole process of scholarly endeavour "involves sifting through evidence and arriving at interpretations" (Said, 2001, p. 282), and critical thinking is invaluable to this process. Having said this, however, it is important to clarify that critical thinking is essential to fruitful rational discussions, but this position does not suggest that primacy be placed on reason over other avenues to knowledge, only that reason should be substantiated by critical thought. Every classroom should have room for students to engage other epistemological or ontological understandings. A truly equitable classroom does not place reason at the core and other ways of knowing at the periphery. As Wilson (2008) asserted, knowledge is relational, and epistemology and ontology can only be understood in relationship. In this relational way of understanding the world and phenomena, of knowledge building and sharing, intuition, dreams, and visions are important, as well as the conventional Western ways of knowing.

\section{THEORY}

Much of what has been recommended throughout this paper has come from the methodologies of social work with groups and adult learning. In these traditions, all members of the class are responsible for the learning process, and learning from colleagues is as important and central as learning from the instructor (Freeman \& Valentine, 1998), a concept that is sometimes difficult for students to accept given years of inculcation in another model. The conventional banking-style education method, with the teacher represented as a banker who makes knowledge deposits in students' minds, is antithetical to post-secondary liberal arts values (Freire, 1970). Borrowed from feminist pedagogy, a better metaphor is that of teacher as midwife who helps draw knowledge out of learners (Merdinger, 1991), a concept that is also consistent with the etymology of the word education, from the Latin educere, meaning "to lead forth." The skilful use of select adult learning principles can help students realize that authority is not solely the jurisdiction of instructors but instead is shared among all group members. In addition, adroit application of these principles can decrease the power imbalance between teacher and student, posit learners as subjects not objects, bring a feminist conceptualization of process orientation, make links between theory and practice, and reveal the impossibility of neutral education (Graham, 1997).

Like all institutions, education, including adult education, is tied to hegemonic interests. This is the case with conventional adult education in which "adult learners seek to obtain from the learning process the means of 'making it' in the system" (Mayo, 1999, p. 139), a phenomenon that is only exacerbated by the commodification and corporatization of higher education, where the emphasis is increasingly on preparing students for the workforce and unapologetically devaluing critical practices (Giroux, 2008; Said, 2001). True transformative liberatory education practices emphasize a commitment to dismantling hegemony and liberating subaltern voices. Moreover, adult educators who have a "social care orientation" bring to the educative process an important power analy- 
sis (Taber, 2011) that interrogates the culpability of corporatization in the production of marginalization, violence, and discrimination. The central goal of adult education practices, which are dedicated to social justice issues and are based on mentoring, collaborative processes, and academic engagement (Mullen, Fish, \& Hutinger, 2010), "has been to produce critical thinkers, who will mobilize to resist oppression" (Ryan, 2001, p. 63). The principles of adult education described here do not involve an abdication of the important role of educator to lead, inspire, facilitate, and guide with the purpose of bolstering "the intellectual projects of critique, of questioning, of coming to understand the difficulties and demands of cultural translation and dissent, and to create a new sense of the public in which oppositional voices are not feared, degraded or dismissed, but valued for the instigation to a sensate democracy they occasionally perform" (Butler, 2004, p. 151). To the contrary, it is imperative that educators seriously negotiate the uneasy tension between power sharing and power holding so that the liberal arts goals of critical engagement, agency, and substantial transformative social change are achieved.

\section{CONCLUSION}

Ferdinand de Saussure identified structure as the meaning-making nexus of language systems (2006). Similarly, structure in the form of safety guidelines is essential to fruitful classroom dialogue, for without structure, meaning can be easily lost, as lack of trust and security prevents achieving a state of open dialogue. Teaching a successful class involves many elements, including interesting course content, sound organization of material, strong grasp of subject, comfortable teaching environment, skilled classroom management, enthusiasm of the instructor, stimulating classroom discussions, good teaching techniques, and sometimes that immeasurable, indefinable quality that cannot be acquired or developed-talent. This paper has argued for the implementation of teaching methodologies that would promote safety for all learners and create a more trusting atmosphere for discussion. Through power sharing, attentiveness, facilitation rather than didacticism, development of collaborative group norms, group work principles, feminist transformative adult learning, and critical thinking, safety can be strongly promoted though never fully attained. However, safety promotion will improve the classroom environment and discussions by creating a discursive space that aims to be hospitable to all and serves as a meeting place for sharing and intellectual and moral growth. An awareness of a shared reality, of our commonness with others, is a fundament of social consciousness and change. Although each human being represents a unique intellectual, emotional, spiritual, historical, and experiential configuration, we inhabit a world with others. Understanding one's self, how one is situated, begins the process of moving from individual self to interconnectedness, making respect for and understanding of others possible. The hope for classroom safety promotion is a plurality of voices and a multiplicity of perspectives, including all persons involved.

At a time when the non-commercial and democracy itself are under siege, and the farreaching cultural politics of neo-liberalism exert a stranglehold on higher education and liberal arts in particular, it is essential that higher education be defended "as a vital public sphere ... necessary to develop and nourish the proper mediation between civil society and corporate power, between identities founded on democratic principles and identities steeped in forms of competitive, self-interested individualism that celebrate selfishness, 
profit-making and greed" (Giroux, 2008, p. 142). As Said (2000) stated, "The university ... is a kind of utopian place, and I would like to preserve it as a place where certain kinds of things are made possible" (p. 436). If education is geared toward both the good of the individual in fostering holistic development and the good of the polity in nurturing persons poised to become engaged citizens capable of imagining a just and equitable future (Appiah, 2005), then classroom safety is a sine qua non for these aims. Through thoughtfully creating safer classrooms that allow for dialogical processes, self-examination, and truly critical pedagogy, we can substantially increase the possibility of graduating persons possessing critical perspectives and highly honed liberatory skills, who are committed to civic engagement and transformative practices and ready to militate against the pervasive and deleterious forces of neo-liberalism.*

\section{REFERENCES}

Adamuti-Trache, M., Hawkey, C., Schuetze, H., \& Glickman, V. (2006). The labour market value of liberal arts and applied education programs: Evidence from British Columbia. Canadian Journal of Higher Education, 36(2), 49-74.

Alter, C., \& Egan, M. (1997). Logic modeling: A tool for teaching critical thinking in social work practice. Journal of Social Work Education, 33(1), 85-102.

Appiah, K. A. (2005). The ethics of identity. Princeton, PA: Princeton University Press.

Axelrod, P., Anisef, P., \& Lin, Z. (2001). Against all odds? The enduring value of liberal education in universities, professions and the labour market. Canadian Journal of Higher Education, 31(2), 47-77.

Biesta, G., \& Stams, G. (2001). Critical thinking and the question of critique: Some lessons from deconstruction. Studies in Philosophy and Education, 20, 57-74.

Briskin, L. (1998a). Negotiating power in the classroom: The example of group work. Canadian Women Studies, 17, 23-28.

Briskin, L. (1998b). Using ground rules to negotiate power in the classroom. In J. Ross Epp (Ed.), Centring on the margins: The evaded curriculum (pp. 25-32). Proceedings of the $2^{\text {nd }}$ bi-annual Canadian Association for the Study of Women and Education (CASWE) International Institute.

Bronstein, L., \& Gibson, C. (1998). Student perceptions of content on oppression: The good news and the bad. Journal of Teaching in Social Work, 17(1/2), 155-167.

Butler, J. (2004). Precarious life: The powers of mourning and violence. New York, NY: Verso.

Campbell, C. (2002). The search for congruency: Developing strategies for antioppressive social work pedagogy. Canadian Social Work Review, 19, 25-42.

Coates, J., \& McKay, M. (1995). Toward a new pedagogy for social transformation. Journal of Progressive Human Services, 6(1), 27-43.

Cohen, M., \& Mullender, A. (2003).Gender and group work. New York, NY: Routledge.

de Saussure, F. (2006). Writings in general linguistics. Oxford, England: Oxford University Press. 
Fleck-Henderson, A. (2002). The modern student and the post-modern curriculum: Developmental issues in learning. Journal of Teaching in Social Work, 22(1/2), 3-15.

Fook, J. (2002). Social work: Critical theory and practice. Thousand Oaks, CA: Sage.

Freeman, M., \& Valentine, D. (1998). The connected classroom: Modeling the evaluation of practice by evaluating the classroom group. Journal of Teaching in Social Work, 17(1/2), 15-29.

Freire, P. (1970). Pedagogy of the oppressed. New York, NY: Seabury.

Garcia, B., \& Melendez, M. (1997). Concepts and methods in teaching oppression courses. Journal of Progressive Human Services, 8(1), 23-34.

Garcia, B., \& Van Soest, D. (1999). Teaching about diversity and oppression: Learning from the analysis of critical classroom events. Journal of Teaching in Social Work, 18(1/2), 149-167.

Garland, J., Jones, H., \& Kolodny, R. (1973). A model for stages of development in social work. In S. Bernstein (Ed.), Explorations in group work: Essays in theory and practice (pp. 17-71). Boston, MA: Milford House.

Giroux, H. (1999). Rethinking cultural politics and radical pedagogy in the work of Antonio Gramsci. Educational Theory, 49(1), 1-19.

Giroux, H. (2008). Against the terror of neoliberalism: Politics beyond the age of greed. Boulder, CO: Paradigm.

Giroux, H. (2011). Neoliberalism and the death of the social state: Remembering Walter Benjamin's angel of history. Social Identities: Journal for the Study of Race, Nation and Culture, 17(4), 587-601.

Giroux, H., \& Giroux, S. (2003). Take back higher education. Tikkun, 18(6), 1-7.

Graham, M. (1997). Empowering social work faculty: Alternative paradigms for teaching and learning. Journal of Teaching in Social Work, 15(1/2), 33-48.

Gutmann, A. (1994). Introduction. In A. Gutmann (Ed.), Multiculturalism: Examining the politics of recognition (pp. 3-24). Princeton, PA: Princeton University Press.

hooks, b. (1994). Teaching to transgress: Education as the practice of freedom. New York, NY: Routledge.

Hulko, W. (2009). The time- and context-contingent nature of intersectionality and interlocking oppressions. Affilia: Journal of Women and Social Work, 24(1), 44-55.

Humphries, B. (1997). The dismantling of anti-discrimination in British social work: A view from social work education. International Social Work, 4O, 289-301.

Hyde, C., \& Ruth, B. (2002). Multicultural content and class participation: Do students self-censor? Journal of Social Work Education, 38(2), 241-256.

Kingwell, M. (2001). The world we want: Virtue, vice, and the good citizen. Toronto, ON: Penguin.

Mayo, P. (1999). Gramsci, Freire \& adult education: Possibilities for transformative action. London, England: Zed Books. 
McKernan, J. (2005). The social market model and higher education: The survival of the richest. College Quarterly, 8(1), 1-5.

McKibben, B. (2007). Deep economy: The wealth of communities and the durable future. New York, NY: Henry Holt.

Mehrotra, G. (2010). Toward a continuum of intersectionality theorizing for feminist social work scholarship. Affilia: Journal of Women and Social Work, 25(4), 417-430.

Merdinger, J. (1991). Teaching women students: Their ways of knowing. Journal of Teaching in Social Work, 5(2), 41-51.

Mezirow, J. (1991). Transformative dimensions of adult learning. San Francisco, CA: Jossey-Bass.

Mulcahy, D. G. (2009). Energizing liberal education. College Quarterly, 12(1), 1-8.

Mullen, C., Fish, V., \& Hutinger, J. (2010). Mentoring doctoral students through scholastic engagement: Adult learning principles in action. Journal of Further and Higher Education, 34(2), 179-197.

Mumm, A., \& Kersting, R. (1997). Teaching critical thinking in social work practice courses. Journal of Social Work Education, 33(1), 75-84.

Nagda, B., Spearmon, M., Holley, L., Harding, S., Balassone, M., Moïse-Swanson, D., \& de Mello, S. (1999). Intergroup dialogues: An innovative approach to teaching about diversity and justice in social work programs. Journal of Social Work Education, 35(3), 433-449.

Northen, H., \& Kurland, R. (2001). Social work with groups (3rd ed.). New York, NY: Columbia University Press.

Perkins, D. (1967). English romantic writers. New York, NY: Harcourt, Brace, Jovanovich.

Plionis, E., \& Lewis, H. (1995). Teaching cultural diversity and oppression: Preparation for risk-The Coverdale model. Journal of Teaching in Social Work, 12(1/2), 175-192.

Popper, K. (1994). The myth of the framework. New York, NY: Routledge.

Raske, M. (1999). Using feminist classroom rules to model empowerment for social work students. Journal of Teaching in Social Work, 19(1/2), 197-209.

Ryan, A. (2001). Feminist ways of knowing: Towards theorising the person for radical adult education. Leicester, England: National Institute of Adult Continuing Education.

Said, E. (1994). Culture and imperialism. New York, NY: Random House.

Said, E. (2000). The Edward Said reader. New York, NY: Vintage.

Said, E. (2001). Power, politics, and culture: Interviews with Edward W. Said. New York, NY: Vantage Books.

Shulman, L. (1987). The hidden group in the classroom: The use of group process in teaching group work practice. Journal of Teaching in Social Work, 1(2), 3-31.

Statistics Canada. (2011). Education indicators in Canada: An international perspective. Ottawa, ON: Statistics Canada. 
Taber, N. (2011). Social care in adult education: Resisting a marketplace agenda. Adult Education Quarterly, 61(4), 376-393.

Taylor, C. (1994). The politics of recognition. In A. Gutmann (Ed.), Multiculturalism: Examining the politics of recognition (pp. 25-74). Princeton, PA: Princeton University Press.

Vainio-Mattila, A. (2009). Internationalizing curriculum: A new kind of education? New Directions for Teaching and Learning,118(Summer), 95-103.

Van Soest, D. (1996a). Impact of social work education on student attitudes and behaviour concerning oppression. Journal of Social Work Education, 32(2), 191-202.

Van Soest, D. (1996b). The influence of competing ideologies about homosexuality on non-discrimination policy: Implications of social work education. Journal of Social Work Education, 32(1), 53-64.

Van Soest, D., Cannon, R., \& Grant, D. (2000). Using an interactive website to educate about cultural diversity and societal oppression. Journal of Social Work Education, 36(3), 463-479.

Wilson, S. (2008). Research is ceremony: Indigenous research methods. Black Point, NS: Fernwood.

Zalstrow, C. (2008). Social work with groups: A comprehensive workbook (7th ed.). Belmont, CA: Brooks Cole.

Zlotkowski, E. (2001). Humanistic learning and service-learning at the liberal arts college. New Directions for Higher Education, 114(Summer), 89-96.

\section{CONTACT INFORMATION}

Arielle Dylan

Assistant Professor

School of Social Work

St. Thomas University

Fredericton NB E3B 5G3 Canada

adylan@stu.ca

Arielle Dylan is an Assistant Professor of Social Work at St Thomas University in Fredericton, New Brunswick, Canada. Her scholarly and research areas include First Nations realities, Roma issues, transnational practices, mental health and addictions, complementary and alternative ontological understandings and wellness approaches, environmental and social justice, and critical pedagogy. She has published in the area of environmental social work, eco-social justice and spirituality, transnational social work, group work, empathic direct practice, and First Nations issues. 